\title{
Genetic Divergence and Chimerism within Ancient Asexually Propagated Winegrape Cultivars
}

\author{
Summaira Riaz, Keith E. Garrison, and Gerald S. Dangl \\ Department of Viticulture and Enology, University of California, Davis, CA 95616 \\ Jean-Michel Boursiquot \\ Etablissement National Technique pour l'Amélioration de la Viticulture, Domaine de l'Espiguette, 30240 Le \\ Grau du Roi, France \\ Carole P. Meredith ${ }^{1}$ \\ Department of Viticulture and Enology, University of California, Davis, CA 95616
}

ADDITIONAL INDEX WORDS. microsatellite, SSR, molecular marker, somatic mutation, grape, Vitis

\begin{abstract}
In total, 25 clones of Vitis vinifera 'Pinot noir' and 22 clones of 'Chardonnay' were analyzed with 100 microsatellite markers, selected from an initial screening of 228 markers. Of the 100 markers, 17 detected polymorphism within one or both of the cultivars. In 'Pinot noir', 15 polymorphic markers detected 15 different genotypes, uniquely distinguished 12 clones out of the 25 and separated the remaining 13 clones into 3 groups. In 'Chardonnay', 9 polymorphic markers detected 9 genotypes and uniquely distinguished 6 clones out of the 22. The remaining 16 clones were separated into 3 groups. For markers that were polymorphic in 'Pinot noir' and 'Chardonnay', none of the variant alleles were common to both cultivars. It is inferred from this result that the natural cross that produced 'Chardonnay' probably occurred when 'Pinot' was still relatively young. Many of the variant genotypes were expressed as three alleles. Further analysis revealed the presence of chimeras in which the third allele was present in leaf but not root or wood tissues, confirming that the grape apical meristem is functionally two-layered. Some clones that share the same microsatellite genotype are documented to have originated in the same locality, suggesting that the origins of undocumented clones may be traced by comparing their microsatellite genotypes with those of well-documented clones. Because clones of 'Pinot noir' and 'Chardonnay' are often visually indistinguishable, microsatellite genotyping may also be useful to detect identification errors in collections and nurseries.
\end{abstract}

Grape cultivars (Vitis vinifera L.) are heterozygous and are therefore propagated asexually in order to maintain their distinctive and economically significant individual characteristics, the most notable of which are the flavors that they impart to wines that are made from them. Many of the best-known wine cultivars are ancient. 'Pinot noir', one of the major winegrapes in the Burgundy and Champagne regions of France, is thought to be at least 2000 years old. The age of 'Chardonnay', widely grown in the same places, is not as well documented but probably exceeds 500 years (Viala and Vermorel, 1902).

Within each of these cultivars, numerous stable subtypes are separately maintained that differ subtly in traits of viticultural or enological interest, such as aroma, color intensity and sugar accumulation. Although some of this variation is attributable to systemic virus infection, much of it is presumed to be genetic, the consequence of differential accumulation of mutations over time within separate somatic lineages. The considerable age of these somatic lineages, centuries and sometimes millennia, uninterrupted by meioses, make grape a highly suitable organism for studying somatic mutation in plants.

A national program to find and evaluate variants within these and other cultivars has been underway in France since 1960 (ENTAV, 1995). Individual vines expressing particularly desirable characteristics have been identified in old vineyards, evaluated in replicated blocks, tested for systemic disease and eventually released as registered numbered clones. Variants of old French cultivars also exist in New World wine regions but their specific European origins and their relationship to registered clones are usually unknown because their history is undocumented.

Received for publication 7 Feb. 2002. Accepted for publication 9 Apr. 2002. We are grateful to Etablissement National Technique pour l'Amélioration de la Viticulture for providing tissue samples of several clones.

${ }^{1}$ Corresponding author; e-mail cpmeredith@ucdavis.edu.
Because winemakers have strong preferences for certain clones, it has become increasingly important to be able to identify them. Morphological differences between clones are slight at best and are often obscured by environmental variables and cultural practices. An objective means by which to distinguish them has long been sought.

In general, DNA markers have either not detected enough polymorphism to differentiate clones or the polymorphism has not been sufficiently reproducible for routine use (Cervera et al., 2000; Regner et al., 2000). Microsatellite DNA profiling is the most robust and widely used method to differentiate grape cultivars but intracultivar microsatellite polymorphism has been detected only rarely (Thomas and Scott, 1993; Bowers, 1998).

Recently, the number of grape microsatellite markers has been increased from $<40$ to $>300$ by the cooperative efforts of an international consortium of 20 research groups in 10 countries. Such a large number of markers increases the probability of detecting rare intracultivar microsatellite polymorphism.

We analyzed clones of 'Pinot noir' and 'Chardonnay' that have diverse geographic origins. Some are registered French clones for which good documentation is available while others have been in California for decades and their French origins are unknown. We have detected reproducible intracultivar microsatellite polymorphism at multiple SSR loci from which we are able to infer common origins for some clones. Furthermore, we find that most of the intracultivar genetic variability is chimeric and we confirm the twolayered nature of the grape meristem.

\section{Materials And Methods}

Clone nomenclature. Grape clones maintained at the University of California at Davis are given a Foundation Plant Materials Service (FPMS) selection number. In those cases where the acces- 
sion is reported to be a registered French clone, the French clone number is maintained in the records but is not used to identify the clone. Until recently, most accessions of French clones came from secondary sources and their clonal identity could not be confirmed. In Table 1, the FPMS number is shown and the French clone number is shown for certain accessions that are reported to be registered French clones.

Plant material. Young leaves and shoot tips were collected from the vineyards of the Department of Viticulture and Enology, the United States Department of Agriculture National Clonal Germplasm Repository, and Foundation Plant Materials Service, all at the University of California at Davis. Clones of Vitis vinifera L. 'Pinot noir' and 'Chardonnay' were chosen to include both registered French clones with well-documented histories and old California selections of unknown origin (Table 1). Several reference samples were also obtained directly from Etablissement National Technique pour l'Amélioration de la Viticulture (ENTAV), which is the repository for registered winegrape clones in France. This enabled us to compare samples from completely independent vines for several clones and also provided some authentic reference samples.

A group of 44 diverse $V$. vinifera cultivars was used to determine the range of allelic diversity for each locus. Genomic DNA was extracted from young leaf tissue either by a modified CTAB procedure as described in Bowers et al. (1993) or with the DNeasy plant minikit (Qiagen, Valencia, Calif.) . Two independent DNA extractions were performed on each sample.

For two clones of 'Pinot noir' and three clones of 'Chardonnay', dormant cuttings were planted in potting soil and kept in a growth chamber for 1 week in order to produce shoots and adventitious roots. Wood tissue was obtained from the dormant canes after the bark and cambium were first scraped away. DNA was extracted from all three tissues with the Qiagen kit.

DETECTION OF POLYMORPHISM. Initially 228 microsatellite markers were amplified in a small pilot set consisting of 1 clone each of 'Cabernet Sauvignon' and 'Riesling' and 4 clones of 'Pinot noir' (Table 1). In total, 67 markers failed to generate any amplification product. Of the 161 remaining markers, 61 were rejected for unclear banding patterns, excessive stutter, or amplification of multiple loci. The remaining 100 markers were amplified in all the clones listed in Table 1. Two 'Pinot noir' and three 'Chardonnay' clones were further investigated for polymorphism in DNA extracted from leaf, root and wood tissue and amplified with seven selected markers.

All of the markers were developed within the Vitis Microsatellite Consortium (VMC) (coordinated by Agrogene, Moissy Crayamel, France). [Primer sequences for some of the markers have been published(DiGasperoetal., 2000; Lefortand Roubelakis-Angelakis, 2000; Sefc et al., 1999), but most will remain proprietary among the VMC members until no later than the end of 2004.] Of the 17

Table 1. Clones analyzed.

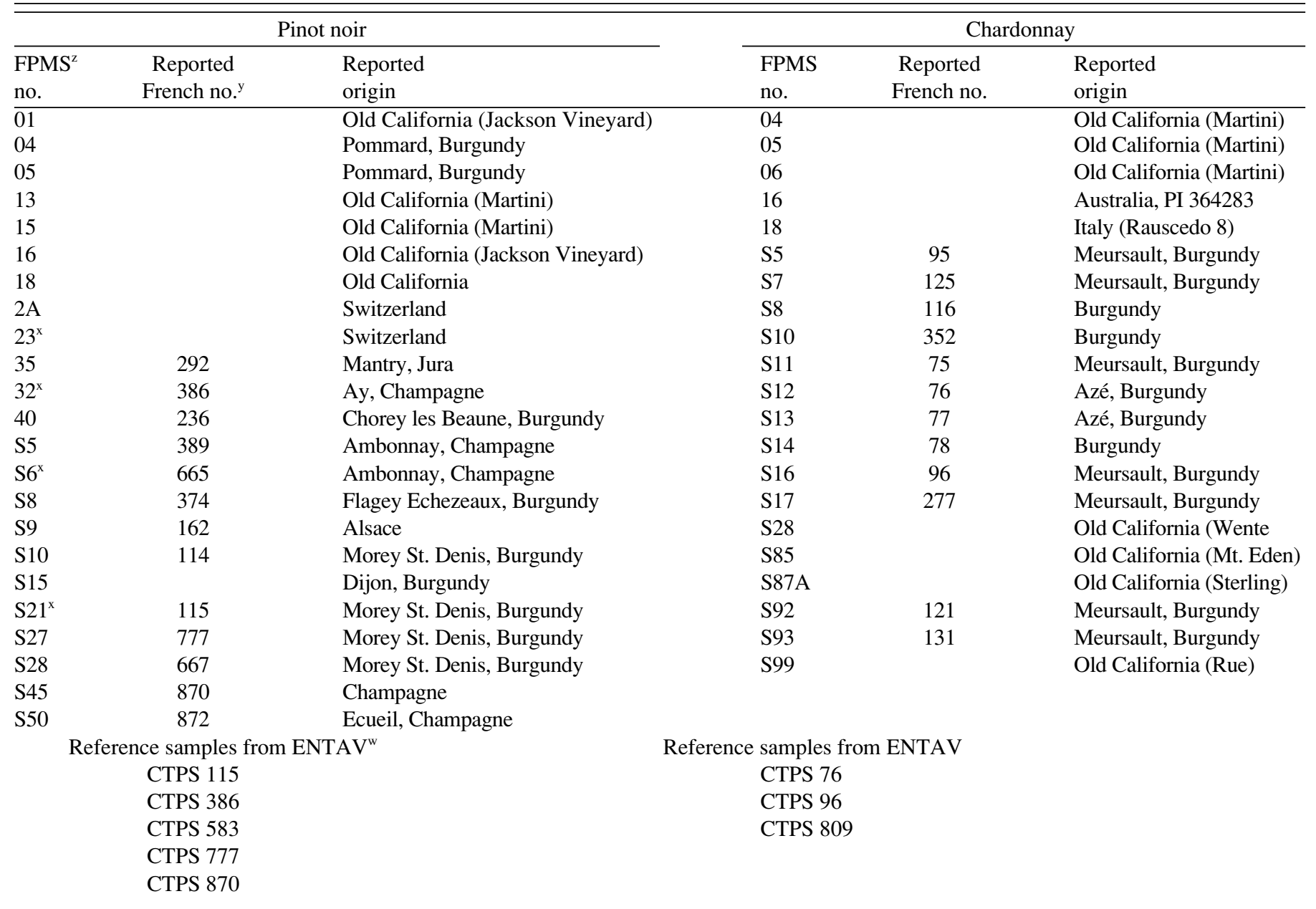

${ }^{\bar{z}}$ Foundation Plant Materials Service, University of California, Davis.

y"Reported" because these plant materials were not obtained directly from ENTAV so their clonal identity cannot be assured.

${ }^{x}$ Used in pilot set to pre-screen markers.

${ }^{w}$ Etablissement National Technique pour l'Amélioration de la Viticulture. 
Table 2. Genotypes of 'Pinot noir' at 15 polymorphic microsatellite loci. Only variant genotypes are shown. All others have the standard genotype shown across the top. Numbers indicate allele sizes in base pairs.

\begin{tabular}{|c|c|c|c|c|c|c|c|c|c|c|c|c|c|c|c|c|}
\hline \multicolumn{2}{|c|}{ Clone } & \multicolumn{15}{|c|}{ Marker } \\
\hline $\begin{array}{c}\text { FPMS } \\
\text { No. } \\
\end{array}$ & $\begin{array}{c}\text { Reported } \\
\text { French } \\
\text { No. } \\
\end{array}$ & $\begin{array}{c}\text { VMC } \\
\text { Ng } 1 \text { b } 9 \\
\end{array}$ & $\begin{array}{c}\text { VMC } \\
8 \mathrm{gg} 6\end{array}$ & $\begin{array}{c}\text { VMC } \\
\text { Ng } 1 \text { e8 } \\
\end{array}$ & $\begin{array}{l}\text { VMC } \\
\mathbf{9 a 3 . 1} \\
\end{array}$ & $\begin{array}{l}\text { VMC } \\
\text { Ng } \\
2 \mathrm{d11} \\
\end{array}$ & $\begin{array}{c}\text { VMC } \\
\text { Ng 2b6 } \\
\end{array}$ & $\begin{array}{c}\text { VMC } \\
1 \mathrm{e8} \\
\end{array}$ & $\begin{array}{l}\text { VMC } \\
1 \mathrm{g3.2} \\
\end{array}$ & $\begin{array}{l}\text { VMC } \\
\mathbf{2 f 1 2} \\
\end{array}$ & $\begin{array}{c}\text { VMC } \\
5 \mathrm{~g} 7 \\
\end{array}$ & $\begin{array}{l}\text { VMC } \\
\text { 5h11 } \\
\end{array}$ & $\begin{array}{c}\mathrm{VMC} \\
\mathrm{Ng} \\
1 \mathrm{d12} \\
\end{array}$ & $\begin{array}{c}\mathrm{VMC} \\
\mathrm{Ng} \\
2 \mathrm{c} 2.1 \\
\end{array}$ & $\begin{array}{c}\mathrm{VMC} \\
\mathrm{Ng} 2 \mathrm{e} 2 \\
\end{array}$ & $\begin{array}{c}\text { VMC } \\
\text { Ng } \\
2 \mathrm{f12} \\
\end{array}$ \\
\hline \multicolumn{2}{|c|}{ Standard genotype } & $\begin{array}{l}158 \\
190\end{array}$ & $\begin{array}{l}150 \\
172\end{array}$ & $\begin{array}{l}124 \\
178 \\
\end{array}$ & $\begin{array}{l}107 \\
161 \\
\end{array}$ & $\begin{array}{l}214 \\
268 \\
\end{array}$ & $\begin{array}{l}123 \\
183 \\
\end{array}$ & $\begin{array}{l}226 \\
230 \\
\end{array}$ & $\begin{array}{l}129 \\
171 \\
\end{array}$ & $\begin{array}{l}196 \\
252 \\
\end{array}$ & $\begin{array}{l}192 \\
220\end{array}$ & $\begin{array}{l}186 \\
202 \\
\end{array}$ & $\begin{array}{l}352 \\
370 \\
\end{array}$ & $\begin{array}{c}236 \\
--\end{array}$ & $\begin{array}{c}181 \\
-\end{array}$ & $\begin{array}{l}183 \\
199 \\
\end{array}$ \\
\hline \multicolumn{17}{|l|}{15} \\
\hline S27 & 777 & & & & & & & & & & & & & & & \\
\hline ENTAV & 777 & & & & & & & & & & & & & & & \\
\hline ENTAV & 870 & & & & & & & & & & & & & & & \\
\hline $\mathrm{S} 50$ & 872 & & & & & & & & & & & & & & & \\
\hline \multicolumn{17}{|l|}{4} \\
\hline \multicolumn{17}{|l|}{5} \\
\hline $\mathrm{S} 10$ & 114 & & & & & & & & & & & & & & & \\
\hline S45 & (870) & & & \multirow{4}{*}{$\begin{array}{l}124 \\
158 \\
178\end{array}$} & \multirow{4}{*}{$\begin{array}{l}107 \\
141 \\
161\end{array}$} & \multirow{4}{*}{$\begin{array}{l}214 \\
254 \\
268\end{array}$} & & & & & & & & & & \\
\hline S5 & 389 & & & & & & & & & & & & & & & \\
\hline S6 & 665 & & & & & & & & & & & & & & & \\
\hline 35 & 292 & & & & & & & & & & & & & & & \\
\hline 32 & 386 & & & & & & \multirow{3}{*}{$\begin{array}{l}123 \\
189\end{array}$} & \multirow{2}{*}{$\begin{array}{l}218 \\
226\end{array}$} & \multirow{2}{*}{$\begin{array}{l}129 \\
151 \\
171\end{array}$} & & & & & & & \multirow{2}{*}{$\begin{array}{l}169 \\
183 \\
199\end{array}$} \\
\hline ENTAV & 386 & & & & & & & & & & & & & & & \\
\hline S21 & 115 & & & & & & & & & & & & & & & $\begin{array}{l}43 \\
183 \\
199 \\
\end{array}$ \\
\hline ENTAV & 115 & & & & & & & & & & & & & & & \\
\hline $\mathrm{S} 28$ & 667 & & & & & & & & & & & & & & & \\
\hline
\end{tabular}

\begin{tabular}{|c|c|c|c|c|c|c|c|c|c|c|c|c|c|c|c|c|}
\hline \multicolumn{2}{|c|}{ Clone } & \multicolumn{15}{|c|}{ Marker } \\
\hline $\begin{array}{c}\text { FPMS } \\
\text { No. }\end{array}$ & $\begin{array}{c}\text { Reported } \\
\text { French } \\
\text { No. } \\
\end{array}$ & $\begin{array}{c}\text { VMC } \\
\text { Ng } 1 \text { b9 } \\
\end{array}$ & $\begin{array}{c}\text { VMC } \\
8 \mathrm{gg}\end{array}$ & $\begin{array}{l}\text { VMC } \\
\text { Ng 1e8 } \\
\end{array}$ & $\begin{array}{l}\text { VMC } \\
\mathbf{9 a 3 . 1} \\
\end{array}$ & $\begin{array}{c}\text { VMC } \\
\text { Ng } \\
2 \mathrm{~d} 11 \\
\end{array}$ & $\begin{array}{c}\text { VMC } \\
\text { Ng 2b6 } \\
\end{array}$ & $\begin{array}{c}\text { VMC } \\
1 \mathrm{e8} \\
\end{array}$ & $\begin{array}{l}\text { VMC } \\
1 \mathrm{g3.2} \\
\end{array}$ & $\begin{array}{l}\text { VMC } \\
2 \mathrm{f12} \\
\end{array}$ & $\begin{array}{l}\text { VMC } \\
5 \mathrm{~g} 7 \\
\end{array}$ & $\begin{array}{l}\text { VMC } \\
\text { 5h11 } \\
\end{array}$ & $\begin{array}{c}\text { VMC } \\
\text { Ng } \\
\text { 1d12 } \\
\end{array}$ & $\begin{array}{c}\text { VMC } \\
\mathrm{Ng} \\
2 \mathrm{c} 2.1 \\
\end{array}$ & $\begin{array}{l}\text { VMC } \\
\text { Ng 2e2 }\end{array}$ & $\begin{array}{c}\text { VMC } \\
\text { Ng } \\
2 \mathrm{fI2} \\
\end{array}$ \\
\hline \multicolumn{2}{|c|}{ Standard genotype } & $\begin{array}{l}158 \\
190 \\
\end{array}$ & $\begin{array}{l}150 \\
172 \\
\end{array}$ & $\begin{array}{r}124 \\
178 \\
\end{array}$ & $\begin{array}{l}107 \\
161 \\
\end{array}$ & $\begin{array}{l}214 \\
268 \\
\end{array}$ & $\begin{array}{r}123 \\
183 \\
\end{array}$ & $\begin{array}{l}226 \\
230 \\
\end{array}$ & $\begin{array}{l}129 \\
171 \\
\end{array}$ & $\begin{array}{l}196 \\
252 \\
\end{array}$ & $\begin{array}{l}192 \\
220 \\
\end{array}$ & $\begin{array}{l}186 \\
202 \\
\end{array}$ & $\begin{array}{l}\mathbf{3 5 2} \\
\mathbf{3 7 0} \\
\end{array}$ & $\begin{array}{c}236 \\
-- \\
\end{array}$ & $\begin{array}{c}181 \\
-\cdots \\
\end{array}$ & $\begin{array}{l}183 \\
199 \\
\end{array}$ \\
\hline 40 & 236 & & & & & & \multirow{2}{*}{$\begin{array}{l}123 \\
185\end{array}$} & & & & & & $\begin{array}{l}332 \\
352 \\
370 \\
\end{array}$ & & & \\
\hline \multicolumn{16}{|l|}{13} & \\
\hline S9 & 162 & & & & & & & & & & & & & & & \\
\hline ENTAV & 583 & \multirow{5}{*}{$\begin{array}{l}158 \\
178 \\
190\end{array}$} & & $\begin{array}{l}124 \\
178 \\
180 \\
\end{array}$ & & & $\begin{array}{l}123 \\
187\end{array}$ & & & \multirow[t]{2}{*}{$\begin{array}{l}196 \\
256\end{array}$} & & & & & & $\begin{array}{l}169 \\
183 \\
199 \\
\end{array}$ \\
\hline S15 & 59 & & \multirow{3}{*}{$\begin{array}{l}150 \\
168 \\
172\end{array}$} & & & & & & & & & & & & & \\
\hline S8 & 374 & & & & & & & & & & & & & & & \\
\hline 18 & & & & & & & & & & & & & $\begin{array}{l}340 \\
352 \\
370 \\
\end{array}$ & & & \\
\hline 1 & & & & & & & & & & & & $\begin{array}{l}186 \\
202 \\
204 \\
\end{array}$ & & & & \\
\hline 16 & & $\begin{array}{l}158 \\
190 \\
192 \\
\end{array}$ & & & & & & & & & & & $\begin{array}{l}336 \\
352 \\
370 \\
\end{array}$ & & & \\
\hline 23 & & & & & & & & & & & 192 & & $\begin{array}{l}332 \\
352 \\
370 \\
\end{array}$ & & $\begin{array}{l}165 \\
181\end{array}$ & 183 \\
\hline $2 \mathrm{~A}$ & & & & & & & & & & & 202 & & & $\begin{array}{r}196 \\
236 \\
\end{array}$ & & --- \\
\hline
\end{tabular}


Table 3. Genotypes of 'Chardonnay' at nine polymorphic microsatellite loci. Only variant tially determined by comparison to a sequencgenotypes are shown. All others have the standard genotype shown across the top. Numbers ing reaction. The ease of scoring for eachmarker indicate allele sizes in base pairs.

\begin{tabular}{|c|c|c|c|c|c|c|c|c|c|c|}
\hline \multicolumn{2}{|c|}{ Clone } & \multicolumn{9}{|c|}{ Marker } \\
\hline $\begin{array}{l}\text { FPMS } \\
\text { No. } \\
\end{array}$ & $\begin{array}{c}\text { Reported } \\
\text { French } \\
\text { No. } \\
\end{array}$ & $\begin{array}{l}\text { VMC } \\
\text { 6c10 }\end{array}$ & $\begin{array}{l}\text { VMC } \\
5 \mathrm{~g} 7\end{array}$ & $\begin{array}{c}\text { VMC } \\
\text { Ng 2f12 }\end{array}$ & $\begin{array}{c}\text { VMC } \\
\text { Ng } 1 \text { b9 }\end{array}$ & $\begin{array}{c}\text { VMC } \\
\text { Ng 2c2.1 }\end{array}$ & $\begin{array}{l}\text { VMC } \\
\text { Ng 1h7 }\end{array}$ & $\begin{array}{l}\text { VMC } \\
\text { Ng 2b6 }\end{array}$ & $\begin{array}{l}\text { VMC } \\
2 \mathrm{fI} 12\end{array}$ & $\begin{array}{l}\text { VMC } \\
\mathrm{Ng} 2 \mathrm{e} 2\end{array}$ \\
\hline \multicolumn{2}{|c|}{ Standard genotype } & $\begin{array}{l}114 \\
140\end{array}$ & $\begin{array}{l}198 \\
220 \\
\end{array}$ & $\begin{array}{l}159 \\
183 \\
\end{array}$ & $\begin{array}{l}158 \\
176 \\
\end{array}$ & $\begin{array}{l}180 \\
236 \\
\end{array}$ & 200 & $\begin{array}{l}123 \\
183 \\
\end{array}$ & $\begin{array}{l}196 \\
252\end{array}$ & $\begin{array}{l}159 \\
181\end{array}$ \\
\hline S11 & 75 & & & & & & & & & \\
\hline $\mathrm{S} 13$ & 77 & & & & & & & & & \\
\hline $\mathrm{S} 14$ & 78 & & & & & & & & & \\
\hline S5 & 95 & & & & & & & & & \\
\hline \multicolumn{11}{|l|}{$\mathrm{S} 87 \mathrm{~A}$} \\
\hline \multicolumn{11}{|l|}{6} \\
\hline \multicolumn{11}{|l|}{18} \\
\hline \multicolumn{11}{|l|}{4} \\
\hline \multicolumn{11}{|l|}{5} \\
\hline S8 & 116 & & & & & & & & & \\
\hline \multicolumn{11}{|l|}{ S99 } \\
\hline $\mathrm{S} 10$ & 352 & & & & & & & & & $\begin{array}{l}159 \\
187\end{array}$ \\
\hline
\end{tabular}
was determined according to the following criteria: ease of amplification, clarity of the bands on the gel, and the complexity of stutter patterns. All gels were visuallyexaminedonalightbox then scanned on a flatbed scanner and stored as digital images.

CONFIRMATION OF POLYMORPHISM. When a presumptive polymorphism was initially observed on a gel, the marker was reamplified from the same DNA extract to rule out the possibility of a PCR artifact. If the polymorphism was still observed, the marker was then amplified from the second independent DNA extraction to confirm the polymorphism.

MARKER REPEAT STRUCTURE. The structure and number of repeat units of each of the markers was obtained from sequence data contributed by members of the Vitis Microsatellite Consortium.

\section{Results}

Of the 100 markers amplified from the complete set of clones, 17 were polymorphic within 'Pinot noir' and/or 'Chardonnay'. (An additional polymorphic marker was so difficult to score that results are not reported.) Most markers detected only two genotypes - the most common (hereafter called standard) genotype and one variant genotype - but five markers in 'Pinot noir' (VMCNg 1b9, VMCNg 1e8, VMCNg 2b6, VMCNg 1d12, VMCNg 2f12) (Table 2) and one in 'Chardonnay' (VMC 5g7) (Table 3) detected more than two genotypes. Some of the most polymorphic markers were also the most difficult to score.

Although the range of repeat lengths did not differ between polymorphic and monomorphic markers (6 to 47 repeat units versus 6 to 49 , respectively) (data not shown), the average uninterrupted repeat length in the polymorphicmarkers was much longer (27.9 versus 15.2 for the monomorphicmarkers)(datanot shown). None of the 12 markers containing tri- or tetranucleotide repeats, in either perfect or compound structures, was polymorphic. The 17 polymorphic markers do not map to clustered locations in the genome (Riaz et al., unpulished data).

In 'Pinot noir', 15 polymorphic markers generated 15 genotypes, uniquely distinguishing 12 clones out of 25 in the set (Table 2). Of the 12 clones, 2 were unique within the set for more than 1 marker. The 13 clones that were not

markers of most interest in this work, primer sequences have been reported for only one, VMC 9a3.1 (http://www.biology.uch.gr/ gvd). Most of the VMC markers are CT dinucleotide repeats. Amplification was performed and confirmed as in Bowers et al. (1999a) and amplification products were electrophoresed on 6\% polyacrylamide gels. Gels were silver-stained according to the protocols and with the reagents provided in the Promega Silver Sequencing Kit (Promega, Madison, Wis.). Allele sizes were ini- uniquely distinguishable formed 3 groups within each of which the members could not be differentiated (Table 2).

In 'Chardonnay', 9 polymorphic markers generated 9 genotypes, uniquely distinguishing 6 clones out of 22 in the set (Table 3 ). None of the 6 clones was unique at more than 1 marker. The 16 clones that were not uniquely distinguishable formed 3 groups within each of which the members could not be differentiated (Table 3 ).

Although 7 of the 17 polymorphic markers were polymorphic in 


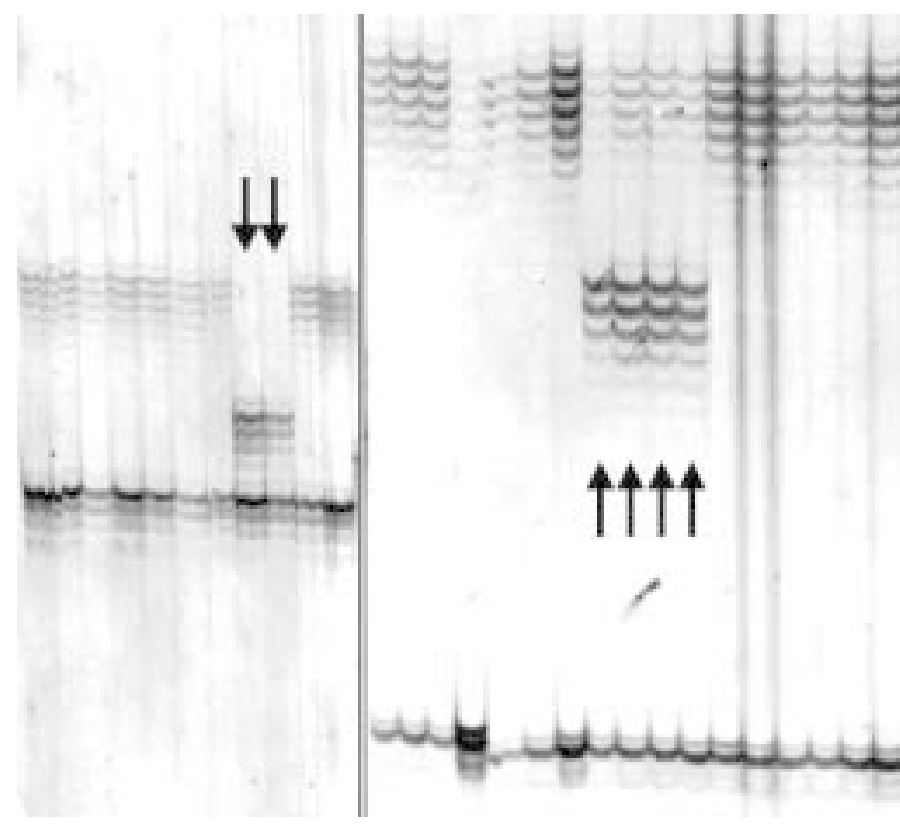

Fig. 1. Examples of polymorphisms observed among clones of 'Pinot noir'. (left) Marker VMC 5g7 detects a different upper allele in clones 23 and 2A. (right) Marker VMCNg 1e8 detects a third allele in clones 35, S45, S6 and S5.

both 'Pinot noir' and 'Chardonnay', none of the variant alleles were common to both varieties (Tables 2 and 3 ). Ease of scoring for some markers differed for the two varieties (Table 3). For example, VMCNg 2c2.1 was easy to score in 'Chardonnay', but moderately difficult to score in 'Pinot noir'.

Polymorphisms were often expressed as the appearance of a third allele (Fig. 1, Tables 2 and 3). This observation prompted a study of chimerism. Leaf, root, and wood DNA from two 'Pinot noir' and three 'Chardonnay' clones was analyzed with seven markers selected to include both two- and three-allele variant genotypes. Variant alleles were detected in three different forms (Table 4): 1) as a third allele in leaf tissue but not detected in wood or root tissue (Fig. 2), 2) as a third allele in the leaf that was also present in wood and root tissue in place of one of the two predominant alleles (Fig. 3 ), and 3 ) as a second allele in leaf, wood and root tissue in place of one of the two predominant alleles (Fig. 2).

\section{Discussion}

Although higher repeat number has been associated with increased microsatellite polymorphism in plants (Loridon et al.,
1998), repeat number would not have helped us to predict which markers were most likely to detect polymorphism among these clones. The range of repeat numbers was similar in the polymorphic and monomorphic markers. However, the much higher average number of uninterrupted repeats in the polymorphic markers suggests that high repeat number is a contributing factor to the polymorphism. Of the 17 polymorphic markers, 10 of them were polymorphic within the pilot set of 4 'Pinot noir' clones with which all markers were initially screened, indicating that prescreening on a small number of geographically diverse clones is an effective predictor of polymorphism among the full set of clones.

Cultivar Differences. More markers were polymorphic in 'Pinot noir' than in 'Chardonnay' (15 versus 9) and more genotypes were observed in 'Pinot noir' than in 'Chardonnay' (15 versus 9, respectively).

Because 'Pinot' is one of the parents of 'Chardonnay' (Bowers et al., 1999b), the two cultivars are expected to share one allele at every locus. In our results, at every locus studied the 'Chardonnay' allele that was inherited from 'Pinot' is the standard allele and never one of the variant alleles. The standard alleles are probably the original genotype of 'Pinot', the variant alleles having accumulated over time in separate somatic lineages of the variety. Although only 7 of the 25 clones of 'Pinot noir' that we analyzed carry the standard alleles for all of the polymorphic markers, the standard genotype would have been predominant when 'Pinot noir' was still a young variety. Thus our results are consistent with an early date for the natural cross that produced 'Chardonnay' because with the passage of time the standard 'Pinot noir' genotype would have become less common and the alleles of that genotype would have been less likely to be transmitted to 'Chardonnay'.

The considerable clonal diversity in 'Pinot noir' has been attributed to increased mutability in the 'Pinot noir' genome (Bernard, 1995). 'Chardonnay' is also quite diverse relative to other varieties, although less so than 'Pinot'. However, the variation observed in 'Chardonnay' includes alleles inherited from both parents, not only 'Pinot', suggesting that if the mutability of 'Chardonnay' is inherited from 'Pinot', it is transactive.

Mechanism of Variation. The absence of meioses over the propagation history of a grape cultivar precludes unequal crossing over or other recombination-based mechanisms for generating allelic variation. Thus the intracultivar microsatellite polymorphism observed in this study must be the result of other mutation mechanisms such as slipped strand mispairing (Fresco and Alberts, 1960) or polymerase slippage (Schlotterer and Tautz, 1992).

The range of allele sizes we observed suggests that more than one mutation mechanism has contributed to the polymorphism. Some variant alleles differ from the standard allele by one or two repeat

Table 4. Microsatellite alleles detected in leaf, wood and root tissue; a and b indicate the two standard alleles, $\mathrm{X}$ and $\mathrm{Y}$ are variant alleles.

\begin{tabular}{|c|c|c|c|c|c|c|}
\hline \multirow{2}{*}{$\begin{array}{l}\text { Grape } \\
\text { type }\end{array}$} & \multirow[b]{2}{*}{ Clone } & \multirow[b]{2}{*}{ Marker } & \multicolumn{3}{|c|}{ Alleles } & \multirow{2}{*}{$\begin{array}{l}\text { Layer } \\
\text { in which } \\
\text { mutation } \\
\text { occurs }\end{array}$} \\
\hline & & & Leaf & Wood & Root & \\
\hline \multirow[t]{4}{*}{ Pinot noir } & CTPS 115 & VMCNg2f12 & $a, b, X$ & $a, b$ & $a, b$ & L1 \\
\hline & CTPS 386 & VMCNg2f12 & $a, b, Y$ & $a, b$ & $a, b$ & L1 \\
\hline & & VMC1g3.2 & $a, b, X$ & $\mathrm{~b}, \mathrm{X}$ & $b, X$ & L2 \\
\hline & & VMC1e8 & $a, b, X$ & $b, X$ & $b, X$ & L2 \\
\hline \multirow[t]{4}{*}{ Chardonnay } & 16 & VMC2f12 & $a, b, X$ & $\mathrm{a}, \mathrm{b}$ & $a, b$ & L1 \\
\hline & S17 & VMCNg1h7 & $a, b, X$ & $a, b$ & $a, b$ & L1 \\
\hline & CTPS 96 & VMC5g7 & $a, b, X$ & $a, b$ & $a, b$ & L1 \\
\hline & & VMC6c10 & $\mathrm{b}, \mathrm{X}$ & $\mathrm{b}, \mathrm{X}$ & $\mathrm{b}, \mathrm{X}$ & $\mathrm{L} 1, \mathrm{~L} 2$ \\
\hline
\end{tabular}


units (e.g., VMC 5g7 in 'Chardonnay' and VMC 2f12 in 'Pinot noir') and others differ by 10 to 20 bp or more (e.g., VMC 9a3.1 in 'Pinot noir' and VMCNg $2 \mathrm{~b} 6$ in 'Chardonnay'). Most of the one or two repeat unit differences are length increases as would be expected from polymerase slippage. The larger length differences occur mainly as new third alleles intermediate in size to the two standard alleles. They are most simply explained as the result of slipped strand mispairing on the larger allele, resulting in a new significantly shorter allele. For the more extreme size differences, we also observed intermediate allele sizes (VMCNg $1 \mathrm{~d} 12$ and VMCNg 2 f12 in 'Pinot noir').

Chimeric nature of VARiation. Although grape apical meristems may have three or more tunica layers in addition to a corpus (Morrison, 1991; Pratt, 1959), they are functionally two-layered, having only two genetically distinct tissue systems (Thompson and Olmo, 1963). The outer tunica layer is stable and histogenetically distinct, but other tunica layers undergo occasional periclinal cell divisions, which lead to layer mixing, and thus are not developmentally independent of the corpus.

Our initial detection of three alleles was from DNA extracted from leaf tissue, which is derived from both the outer tunica layer (L1) and the inner cell layers (L2). Franks et al. (2002) have also observed three alleles at some microsatellite loci in some grape clones. The presence of three alleles suggests a periclinal chimera in which a mutant allele is present in only one of the two layers. If adventitious roots and internal stem tissues (including secondary phloem, xylem, and pith) originate exclusively from the L2 as

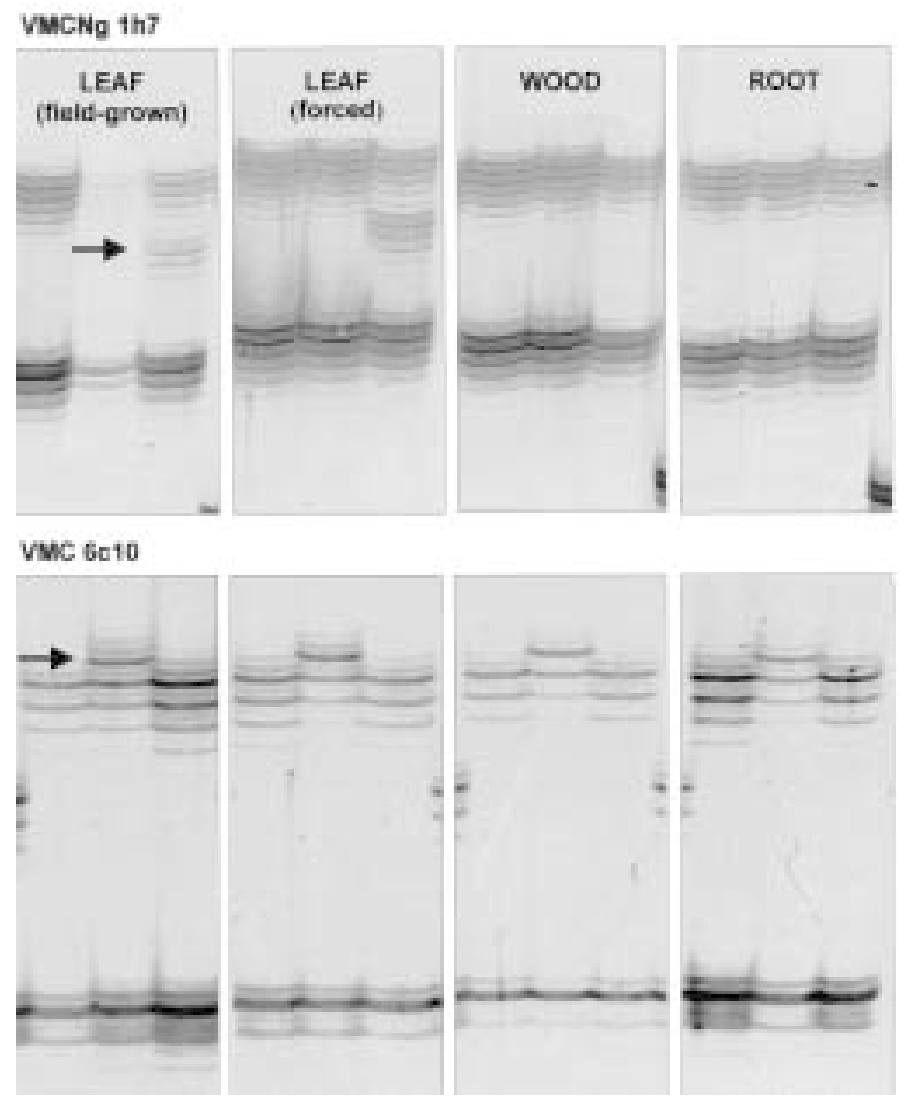

Fig. 2. Tissue specificity of microsatellite polymorphism in three clones of Chardonnay, FPMS 16 (left), ENTAV 96 (center) and FPMS 51 (right), all analyzed with markers VMCNg $1 \mathrm{~h} 7$ and VMC 6c10. VMCNg $1 \mathrm{~h} 7$ detects three alleles in leaf tissue of FPMS 51 but only two alleles in wood and root tissue. VMC6c10 detects a polymorphic large allele (arrow) in all tissues tested of FPMS 31. FPMS 16 has the standard genotype for both markers and all tissues tested. reported (Pratt, 1959), the genotype of these tissues will not include any allele that exists only in the L1 layer.

We analyzed leaf, root and wood tissue from several samples to look for layer-specific mutations and we observed alleles that are restricted to either the L1 or L2 layers. For example, 'Pinot noir' clone CTPS 115 at marker VMCNg2f12 has three alleles in leaf tissue (the two standard alleles plus a new third one) while wood and root tissues have only the two standard alleles (Table 4). Thus it is likely that this mutation occurred in a cell in the L1 layer, resulting in three alleles in leaf tissue, because it includes both L1 and L2 and the wood and root tissue are derived only from L2. 'Pinot noir' clone CTPS 386 at marker VMC1e8 also has three alleles in leaf tissue and only two in wood and root tissue, but in this case the new allele is present in all three tissues, consistent with a mutation in the L2 layer (Table 4). We never observed a genotypic difference between root tissue and stem tissue nor did we ever see three alleles in root or stem tissue. Our results are thus consistent with root and wood tissues in grape having their origin in a single histogenic layer of the meristem.

We observed many cases in which a new allele replaced one of the standard alleles and no third allele was detected. In the one such case that we investigated further ('Chardonnay' clone CTPS 96 at VMC 6c10), the new allele was present in all three tissues (Table 4). It is unlikely that this 2-bp length mutation occurred independently in L1 and L2 (although we did not sequence the allele from separate tissues to confirm that it is the same allele). It is more likely that the mutation occurred in an L1 or an L2 cell and then came to populate both layers of the meristem, either through a rare periclinal cell division in L1 or an injury to L1, which resulted in L2 cells forming the superficial layer (Thompson and Olmo, 1963).

Marcotrigiano (2000) has shown that meristem layer integrity can be disrupted by herbivory. When terminal and primary axillary shoots are removed, shoots then grow from secondary axillary buds, the meristems of which do not always maintain the same cell lineage as the main shoot. While some of the chimeric genotypic variation within old grape cultivars may be the result of herbivory, it may also be the consequence of frost damage, which also can destroy primary meristems and result in shoot outgrowth from secondary meristems in dormant buds. Both 'Pinot noir' and 'Chardonnay' are traditionally cultivated in parts of France that are at the northern limit of

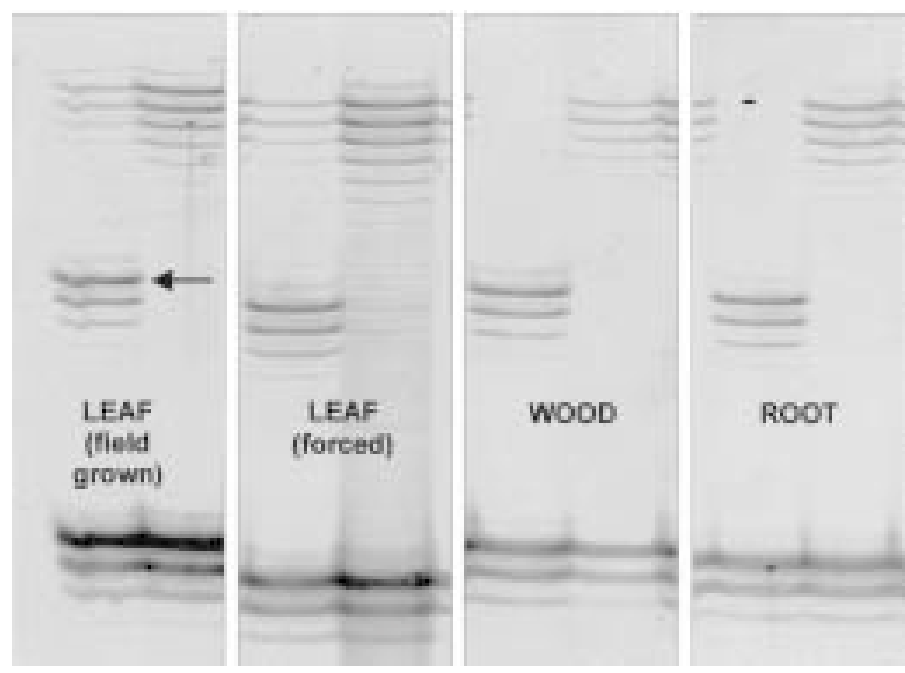

Fig. 3. Tissue specificity of microsatellite polymorphism in two clones of Pinot noir, FPMS 32 (left) and FPMS S21 (right), both analyzed with marker VMC 1g3.2. Three alleles in are detected in leaf tissue of FPMS 32. In wood and root tissue, the variant middle allele (arrow) is also present but the upper original allele is absent. FPMS S21 has the standard genotype in all tissues analyzed. 
viticulture and are regularly subject to spring frost damage. Perhaps frost injury has been a contributing factor to the clonal diversity in these two cultivars.

SHARED MUTATIONS AND COMMON ORIGINS. Many of the variant alleles that we observed are shared by two or more clones. The shared alleles may be the consequence of a common origin and propagation history, particularly those mutations that differ from the standard genotype by more than two or three repeat units. The absence of complete clonal identity is probably the result of further clonal divergence after the occurrence of the shared mutations.

For example, the only two 'Pinot noir' clones from Switzerland (2A and 23) are distinguishable from all the others by a distinct genotype at 2 loci (VMC $5 \mathrm{~g} 7$ and VMCNg 2f12). Similarly, 'Chardonnay' S7, S16, S92, and S93 all have the same variant genotypes at two loci, one of which is chimeric (VMC 6c10 and VMC 5g7). They are reported to be French clones 125, 96, 121 and 131 , respectively, all of which were originally selected in the village of Meursault in Burgundy (ENTAV, 1995). Similarly, 'Pinot noir' S21 and S28, reported to be French clones 115 and 667, respectively, have the same variant alleles at 2 loci, 1 of which is chimeric. Both French clones were selected in Morey St. Denis in Burgundy (ENTAV, 1995). 'Pinot noir' S5 and S6, which share the same chimeric genotype at 3 loci, are reported to be French clones 389 and 665 , both of which were selected in the village of Ambonnay in the Champagne region (Barillere et al., 1995). Clone 292 also has the same genotype but was selected in the village of Mantry, Jura (ENTAV, 1995). It is improbable that the same chimeric genotype arose independently in the two regions so it is likely that 292 originated in Champagne and was taken to Jura or that a progenitor or 389 and 665 originated in Jura and was taken to Champagne. Further analysis of additional clones from both regions might reveal in which of the two regions the genotype arose.

The origins of European winegrape accessions that are not welldocumented may be discovered by comparison to registered clones. The source of 'Pinot noir' 18, for example, is unknown. It shares the genotype of 'Pinot noir' S8 at two loci, both of which are chimeric, indicating that the two have a common history. 'Pinot noir' S8 is reported to be clone 374 from the village of Flagey Echezeaux in Burgundy so 'Pinot noir' 18 may also have originated there.

Practical applications. Microsatellite polymorphism may be useful for detecting identification errors in winegrape clones. Although some markers can uniquely differentiate certain 'Pinot noir' and 'Chardonnay' clones from the others within a known group, they cannot positively identify a clone because unknown clones not included in the group might share the same genotype. However, exclusion based on the absence of a match with an authentic reference can be a valuable means to detect propagation and recordkeeping errors. Our study has already detected such an error. 'Pinot noir' S45 in Davis is reported to be the French clone 870, although it was not obtained directly from ENTAV, the French clone repository. Our results show, however, that the Davis accession differs from the authentic French sample of 870 at three markers, demonstrating that the Davis accession is incorrectly identified. Conversely, the Davis accessions that are reported to be the French 'Pinot noir' clones 115, 386, and 777 and the French 'Chardonnay' clones 76 and 96 all have the same genotype as the authentic French reference samples and in four of these five cases the genotype is not the common standard genotype. While this finding does not constitute positive verification of the identity of these Davis accessions, it is evidence in support of their correctly identity.

Our results clearly demonstrate that clonal diversity within ancient winegrape cultivars has a genetic basis. Although other factors are not ruled out, we have shown that genotypic divergence can be accounted for by the differential accumulation of somatic mutations in different somatic lineages. Associations between certain genotypes and documented shared geographic origins suggests that microsatellite genotypic differences may provide a means by which to infer the origins of poorly documented clones, particularly those in New World wine regions. Finally, these differences provide a means to detect identification errors in foundation plantings and nurseries where many morphologically indistinguishable clones are maintained.

\section{Literature Cited}

Barillere, J.M., A. Collas, C. Bougerey, and C. Palge. 1995. Clonal Selection in Champagne, p. 33-39. In: Proc. Amer. Soc. Enol. Viticult. Intl. Symp. Clonal Selection, 20-21 June 1995, Portland, Ore.

Bernard, R. 1995. Aspects of clonal selection in burgundy. In: Proc. Amer. Soc. Enol. Viticult. Intl. Symp. Clonal Selection, 20-21 June 1995, Portland, Ore.

Bowers, J.E., E.B. Bandman, and C.P. Meredith. 1993. DNA fingerprint characterization of some California winegrape cultivars. Amer. J. Enol. Viticult. 44:266274.

Bowers, J.E. 1998. The use of simple sequence repeat (SSR) and amplification fragment length polymorphism (AFLP) markers for analysis of interrelationships and origins of winegrape cultivars. PhD diss. Univ. Calif., Davis.

Bowers, J.E., G.S. Dangl, and C.P. Meredith. 1999a. Development and characterization of additional microsatellite DNA markers for grape. Amer. J. Enol. Viticult. 50:243-246.

Bowers, J.E., J.M. Boursiquot, P. This, K. Chu, H. Johansson, and C.P. Meredith. 1999b. Historical genetics: The parentage of Chardonnay, Gamay, and other wine grapes of northeastern France. Science 286:1562-1565.

Cervera, M.T., J.A. Cabezas, E. Sanchez-Escribano, J.L. Cenis, and J.M. MartinezZapater. 2000. Characterization of genetic variation within table grape varieties (Vitis vinifera L.) based on AFLP markers. Vitis 39:109-114.

Di Gaspero, G., E. Peterlunger, R. Testolin, K.J. Edwards, and G. Cipriani. 2000. Conservation of microsatellite loci within the genus Vitis. Theor. Appl. Genet. 101:301-308

ENTAV. 1995. Catalogue des Variétés et Clones de Vigne Cultivés en France. Etablissement National Technique pour l'Amélioration de la Viticulture, Le Grau du Roi, France.

Franks, T., R. Botta, and M. R. Thomas. 2001. Chimerism in grapevines: implications for cultivar identity, ancestry and genetic improvement. Theor. Appl. Genet. (in press)

Fresco, J. R. and B. M. Alberts. 1960. The accommodation of non-complementary bases in helical polyribonucleotides and deoxyribonucleic acids. Proc. Natl. Acad. Sci. USA. 85:311-321

Lefort, F. and K. A. Roubelakis-Angelakis, 2000. The Greek Vitis Database http:/ /www.biology.uch.gr/gvd/

Loridon, K., B. Cournoyer, C. Goubely, A. Depeiges, and G. Picard. 1998. Length polymorphism and allele structure of trinucleotide microsatellites in natural accessions of Arabidopsis thaliana. Theor. Appl. Genet. 97:591-604.

Marcotrigiano, M. 2000. Herbivory could unlock mutations sequestered in stratified shoot apices of genetic mosaics. Amer. J. Bot. 87:355-361.

Morrison, J. 1991. Bud development in Vitis vinifera L. Bot. Gaz. 152:304-315.

Pratt, C. 1959. Radiation damage in shoot apices of Concord grape. Amer. J. Bot. 46:103-109

Regner, F., E. Wiedeck, and A. Stadlbauer. 2000. Differentiation and identification of White Riesling clones by genetic markers. Vitis 39:103-107.

Schloetterer, C. and D. Tautz. 1992. Slippage synthesis of simple sequence DNA. Nucleic Acids Res. 20:211-216

Sefc, K.M., F. Regner, E. Tureschek, J. Glossl, and H. Steinkellner. 1999. Identification of microsatellite sequences in Vitis riparia and their application for genotyping of different Vitis species. Genome 42:367-373

Thomas, M.R. and N.S. Scott (1993) Microsatellite repeats in grapevine reveal DNA polymorphisms when analysed as sequence-tagged sites (STSs). Theor. Appl. Genet. 86:985-990

Thompson, M.M. and H.P. Olmo. 1963. Cytohistological studies of cytochimeric and tetraploid grapes. Amer. J. Bot. 50:901-906

Viala, P. and V. Vermorel. 1902. Ampélographie. vol. IV. Masson, Paris. 